\title{
Role of Chemosensory TRP Channels in Lung Cancer
}

\author{
Thomas R. H. Büch ${ }^{1, *}$, Eva A. M. Büch ${ }^{1}$, Ingrid Boekhoff ${ }^{2}$, Dirk Steinritz ${ }^{2,3}$ and Achim Aigner ${ }^{1, *}$ \\ 1 Rudolf Boehm-Institute for Pharmacology and Toxicology, Clinical Pharmacology, Leipzig University, \\ Haertelstrasse 16-18, D-04107 Leipzig, Germany; eva.schaefer@lrz.uni-muenchen.de \\ 2 Walther Straub Institute of Pharmacology and Toxicology, Ludwig-Maximilian University, \\ D-80336 Munich, Germany; ingrid.boekhoff@lrz.uni-muenchen.de (I.B.); \\ dirk.steinritz@lrz.uni-muenchen.de (D.S.) \\ 3 Bundeswehr Institute of Pharmacology and Toxicology, Neuherbergstr. 11, D-80937 Munich, Germany \\ * Correspondence: thomas.buech@medizin.uni-leipzig.de (T.R.H.B.); \\ achim.aigner@medizin.uni-leipzig.de (A.A.); Tel.: +49-(0)341-972-4661 (T.R.H.B.); Fax: +49-(0)341-972-4669
}

Received: 9 August 2018; Accepted: 18 September 2018; Published: 21 September 2018

\begin{abstract}
Transient receptor potential (TRP) channels represent a large family of cation channels and many members of the TRP family have been shown to act as polymodal receptor molecules for irritative or potentially harmful substances. These chemosensory TRP channels have been extensively characterized in primary sensory and neuronal cells. However, in recent years the functional expression of these proteins in non-neuronal cells, e.g., in the epithelial lining of the respiratory tract has been confirmed. Notably, these proteins have also been described in a number of cancer types. As sensor molecules for noxious compounds, chemosensory TRP channels are involved in cell defense mechanisms and influence cell survival following exposure to toxic substances via the modulation of apoptotic signaling. Of note, a number of cytostatic drugs or drug metabolites can activate these TRP channels, which could affect the therapeutic efficacy of these cytostatics. Moreover, toxic inhalational substances with potential involvement in lung carcinogenesis are well established TRP activators. In this review, we present a synopsis of data on the expression of chemosensory TRP channels in lung cancer cells and describe TRP agonists and TRP-dependent signaling pathways with potential relevance to tumor biology. Furthermore, we discuss a possible role of TRP channels in the non-genomic, tumor-promoting effects of inhalational carcinogens such as cigarette smoke.
\end{abstract}

Keywords: TRP; TRPA1; lung cancer; TRPV1; tumor-promoting effects

\section{Introduction}

Lung cancer can be divided into four subtypes: adenocarcinoma ( $40 \%$ of all cases), squamous carcinoma (30\%), large cell carcinoma and small cell carcinoma (SCLC) (15\% each) [1]. Due to their clinical similarities, adeno-, large cell and squamous cell carcinoma are often grouped as non-small cell lung carcinoma (NSCLC). In NSCLC therapy, remarkable progress has been made in the last $\sim 15$ years, including targeted therapies and immunotherapies such as EGFR blockers, dual kinase inhibitors or check point inhibitors [2-4] that are usually combined with classical and well-established chemotherapies (etoposide, cisplatin). However, there is still an urgent need for improved therapeutic strategies based on the interference of critical oncogenic signaling pathways. In the case of SCLC, the therapeutic options have even more limitations. SCLC patients often present with advanced disease at the time of diagnosis, i.e., with metastases, thus limiting local therapy options (surgery or other local intervention, local radiation) in favor of combination chemotherapy $[5,6]$. Due to its rapid proliferation rate, the initial response is often remarkably high, with, unfortunately, subsequent development of chemoresistance and disease progress, which highlights the need for novel target molecules and pathways and more detailed knowledge regarding underlying drivers of SCLC carcinogenesis [7]. 
To date, novel therapeutic approaches targeting specific oncogenic signaling pathways have focused on the interference of critical membrane receptors (e.g., receptor tyrosine kinases) or downstream signaling molecules (e.g., receptor-regulated kinases or transcription factors). However, the modulation of tumor-relevant ion channels (by stimulating tumor-inhibiting channels or by blocking tumor-promoting channels) represents an interesting alternative concept. Thus, TRP (transient receptor potential) channels are promising candidates for innovative anticancer therapies [8].

The discovery of TRP channels is related to a Drosophila mutant already described in the 1960s [9] showing an altered light reaction. The TRP-gene encoding a rhodopsin-activated calcium channel was cloned 20 years later [10]. Subsequent studies indicated the existence of multiple different TRP homologues in other species [11]. Thus, TRP channels comprise a large and divergent family of channel proteins, expressed in various tissues and cell types in vertebrates as well as in invertebrates. A common feature of the TRP superfamily of cation channels are six transmembrane segments and a certain sequence homology. On the other hand, the major differences to other families of ion channels lie in their diversity of cation selectivities and specific mechanisms of activation. Notably, a given TRP channel can be activated, and its response can be modulated by entirely different mechanisms, which has led to the concept of TRP channels as 'multiple signal integrators'. Furthermore, another common feature seems to lie in the TRP channels' response to all large classes of external stimuli such as light, sound, chemicals, temperature, changes in osmolarity and direct contact [12-14].

The TRP superfamily can be subdivided into six subfamilies that are ordered into two groups: group 1 comprises the subfamilies TRPC (canonical), TRPV (vanilloid), TRPM (melastatin) and TRPA (ankyrin), while group 2 consists of only two subfamilies, TRPP (polycystin) and TRPML (mucolipin) [12,15]. It is not possible to predict the mechanism(s) of activation of a given channel based on its affiliation to a subfamily. Moreover, natural compounds such as capsaicin or menthol activate the heat-sensitive TRPV1 and the cold-sensitive TRPM8 channels, defining these channels as not only temperature sensors but also chemosensory channels.

In the following, TRP subfamilies, which include chemosensory channels, e.g., TRPV, TRPM, and TRPA are briefly characterized. The 'classical' TRPC channels (for a review see: [16-18] are not chemosensory channels sensu stricto and are therefore omitted.

TRPV channels share about $25 \%$ sequence homology with the TRPC channels in a region spanning the transmembrane domains 5 and 6. TRPV1 is activated by heat $\left(\geq 43^{\circ} \mathrm{C}\right)$ [19] and chemicals such as endocannabinoids, anandamide, camphor and others, with low $\mathrm{pH}$, ethanol, nicotine or pro-inflammatory cytokines leading to further enhancement of cation flux. Again, this leads to the concept of TRPV1 acting as a multiple signal integrator. TRPV2, TRPV3 and TRPV4, but not TRPV5 and V6, are also heat activatable [14].

The TRPM channels share about 20\% amino acid sequence identity with the TRPC channels over the five C-terminal transmembrane domains and contain a TRP domain C-terminally to the transmembrane segments [20]. While the total length and sequence of their C-terminal regions shows major differences, they can be subdivided into three subfamilies: TRPM1/3, TRPM4/5 and TRPM6/7. Despite some similarities, TRPM2 and M8 do not form another subfamily. TRPM1 was the first TRPM identified in mammals [21], and in some melanoma cell lines its expression level inversely correlates with their metastatic potential. TRPM4 and M5 are voltage gated, calcium-activated, monovalent cation-selective channels (VCAMs), based on a short acidic stretch of six amino acids in the pore loops. TRPM2, M6 and M7 are characterized by a C-terminal kinase domain allowing for channel-independent signaling and are therefore designated as chanzymes. TRPM7 is a divalent-permeable cation channel that conducts, inter alia, $\mathrm{Mg}^{2+}$ ions, which in turn regulate the channel activity (as free $\mathrm{Mg}^{2+}$ or Mg-complexed nucleotides).

TRPA1 is the only member of the TRPA channels to have been characterized in man so far (for a review see: [22]). It is characterized by the presence of around 17 ankyrin-repeats in its N-terminus. Furthermore, it contains a zinc binding site in the C-terminus and a calcium binding site in the $\mathrm{N}$-terminus. To date, three cysteine residues have been identified that are thought to be responsible 
for TRPA1 activation through covalent modification $[23,24]$. TRPA1 is activated by a wide variety of substances [25]. Of note, beyond the 'classical' mechanism that relies on the binding of agents in their binding pocket (key lock principle), many electrophilic compounds activate TRPA1 through a specific mechanism, i.e., their covalent coupling to TRPA1. Below, activators of TRPA1, especially with tumor-biological relevance, will be discussed in more detail.

\section{Airway Expression of Chemosensory TRP Channels}

TRP channels are expressed throughout the airways from the nasal mucosa to the alveolo-capillary system. They have been found in neuronal cells in the airways, especially in the nerve endings of $C$ fibers, but also in non-neuronal cells, e.g., in the pulmonary epithelium, in smooth muscle cells of the bronchi and vasculature as well as in pulmonary endothelial cells.

Regarding the function of TRP channels (in particular TRPA1 and TRPV1) in neuronal cells, a critical role as toxicant sensor has been established (for review: [26,27]). The activation of these sensory TRP channels in the nerve endings of the airways leads to the stimulation of protective reflexes (cough, increased mucus production, enhanced mucociliary clearance) [27-30], but also to neurogenic inflammation, which suggests an involvement of these channels in chronic obstructive lung diseases (asthma, COPD).

Of note, sensor TRPs, like TRPV4 or TRPA1 have recently been described in non-neuronal cells as well [31-33].

In fact, TRPV4 has been found expressed in many ciliary cells, e.g., in the ovarian duct [34], in cholangiocytes [35], and in bronchial epithelial cells [36,37]. The stimulation of tracheal cells with ATP, a well-known activator of ciliary beat frequency in the bronchial system, led to a receptor-operated calcium signal strongly dependent on TRPV4 [36]. Intriguingly, the activation of TRPV4 has been described as stimulating the release of ATP by airway epithelial cells, a process that is induced by cell swelling in a pathway involving pannexin 1, RhoA and myosin light chain phosphorylation [37]. These findings suggest that TRPV4 and ATP may form a part of a self-amplifying system with TRPV4 being responsible for ATP-promoted calcium signaling and the subsequent triggering of ATP release with activation.

The TRPA1 channel has long been regarded as a sensor protein for harmful stimuli (for a review, see: [25]) mainly expressed in neuronal and neuroendocrine cells. However, non-neuronal functions of this channel, especially in the context of the airway epithelium have been proposed in recent years (for a review, see: [26,38]).

\section{TRP Channels and Cancer}

The involvement of TRP channels in tumor-relevant processes is plausible since calcium per se as well as calcium-dependent signaling molecules, play a pivotal role in the regulation of proliferation, apoptosis and cellular differentiation [39-42]. In fact, an association with cancer has been suggested for a number of chemosensory TRP channels based on altered expression levels (up- or downregulation in cancerous tissue as compared to normal tissue) or functional studies (TRP-promoted stimulation of oncogenic signaling and/or tumor-promoting or inhibitory effects). Of note, most analyses of TRP channels in cancer cells did not find critical mutations in these proteins that would affect the channel activity, but instead altered the expression levels of wild-type channels on the mRNA and/or protein level [42].

It is remarkable that some members of the TRP family have been found to be involved in tumor-promoting processes, whereas other TRP channels have been linked with the suppression of tumor growth. The postulated opposing functions of TRP channels are in line with the complex role of calcium in the orchestration of cell growth as well as apoptosis.

Regarding the family of TRPM (melastatin) channels, a number of members have been associated with tumor progression (see [43] for a review). For example, the founding member, TRPM1 was first described as a gene downregulated in melanoma cells as compared to benign melanocytes [21,44]. 
This led to the hypothesis of TRPM1 acting as a tumor suppressor (hence the name melastatin). In line with this assumption, the induction of cellular differentiation in melanoma cells by treatment with hexamethylenbisacetamide caused an upregulation of TRPM1 transcripts [45]. In contrast to the potential tumor suppressor TRPM1, other members of this family have been implicated in oncogenic processes. For example, TRPM8 (initially named Trp-p8) was first been described in a screening experiment analyzing upregulated transcripts in prostate cancer tissue [46]. Since then, a number of reports have shown that this channel is involved in various tumor-biology relevant processes in prostate cancer (for a review, see [47]).

Likewise, a role in cancer cells has been described for several members of the TRPV family. For example, an implication of TRPV1 in the regulation of apoptotic pathways induced by cannabinoids in gynecologic carcinoma was described [48-50]. Another member of the TRPV family, TRPV6, is overexpressed in prostate cancer [51] and the expression level has been correlated with tumor grading, suggestive of a potential oncogenic role of TRPV6 in this tumor entity.

With respect to the TRPA1 channel, most publications addressing a protective role in cancer cells focus on lung cancer (see below). Of note, the very first papers identifying and describing TRPA1 [52,53] associated this protein with a tumor-suppressor function, since its expression was downregulated in tumor cells. It was only later that studies identified this novel protein as an important chemosensor for pain-eliciting substances or potentially harmful irritants [54]. While this finding shifted the interest in the TRPA1 field from tumor cells to neuronal or toxicological aspects of this channel, it was also found that TRPA1 may exert tumor-promoting effects (see below).

\section{Expression of Sensory TRP Channels in Lung Cancer Cells}

A functional expression of TRPA1 in lung cancer cells has been detected in a broad panel of SCLC cell lines [55]. As mentioned above, SCLC cells show many neuroendocrine features, so that the expression of TRPA1 in these cells is in line with the well-established role of this channel in neurons [54,56-59] or neuroendocrine cells [60-63]. In SCLC cells, the activation of TRPA1 led to increased cell survival [55], in line with a potential role of TRPA1 in the regulation of apoptosis under stress conditions (see also next paragraph). Interestingly, in Lewis lung carcinoma cells both TRPA1 and TRPM8 were functionally expressed and regulated critical cellular functions (metastasis, autophagy, energy metabolism) [64].

Expression of TRPV1 has been demonstrated in lung adenocarcinoma cells [65-67]. TRPV1 expression has also been also demonstrated in lung fibroblasts [68] as well as in normal lung epithelium and sensory nerves (see above). Thus, the expression of this channel in lung tumors may be in part attributable to non-malignant stroma cells.

Moreover, Li et al. reported that TRPV3 was overexpressed in NSCLC tissue as compared to adjacent noncancerous lung tissue [69] and that TRPV3 overexpressed was correlated with worse survival rates.

\section{Activation of Sensory TRP Channels by Inhalative Carcinogens and Chemotherapeutics}

TRPV1 and TRPA1 are involved in the detection of potentially harmful inhalants, e.g. by reactive electrophiles. However, these channels display a remarkable promiscuity with regard to their activators. For example, TRPA1 is activated by a large number of chemically unrelated substances (Table 1). Regarding the activation mechanism, the TRP channel can be stimulated by the direct reaction of the cysteine residues of the channel with an electrophilic agent $[23,24,70]$, or by the reaction of the electrophilic compounds with constituents of the plasma membrane leading to the generation of secondary TRP activators [71,72]. 
Table 1. Overview of some established TRPA1 activators with potential pathogeneic or therapeutic relevance for lung tumors.

\begin{tabular}{ccc}
\hline Substance & Potential Source & References \\
\hline Acrolein & Cigarette smoke & {$[73,74]$} \\
2-Chloroethyl-ethylsulfide & Analogue of sulfur mustard & {$[75]$} \\
Crotonaldehyde & (chemical warfare agent) & {$[73]$} \\
Formaldehyde & Cigarette smoke & {$[76]$} \\
Hydrogen peroxide & Cigarette smoke & {$[74,77]$} \\
Nicotine & Endogenous inflammatory mediator & {$[76]$} \\
Nitric oxide & Cigarette smoke & {$[78,79]$} \\
Oxaliplatin & Endogenous inflammatorymediator & {$[76]$} \\
& Chemotherapeutic agent & {$[80,81]$} \\
\hline
\end{tabular}

In the case of TRPA1, it has been shown that tumor-relevant compounds like cigarette smoke or DNA-damaging electrophiles can activate this channel [73-75]. Of note, the activation of TRPA1 in SCLC cells can promote cell survival [55] suggesting a potential role in tumor progression. Moreover, in lung adenocarcinoma cells, a direct interaction of TRPA1 with FGFR2 has been demonstrated, which may regulate the metastatic propensity of the cancer cells [82]. Thus, apart from the well-established direct genotoxic, tumor-initiating effects of DNA-damaging electrophiles, TRPA1 may also provide the mechanistic basis for a tumor-promoting role of these compounds via their potential to modify critical proteins like Keap1 or TRP channels (see Figure 1) with possible therapeutic implications. In this context, it is noteworthy that Takahashi et al. recently demonstrated an increased cellular resistance towards oxidative stress in breast and in lung cancer spheroids dependent on TRPA1 function [83]. In this latter paper, a self-amplifying mechanism was suggested, since reactive chemicals can activate NRF2-regulated transcription, which in turn leads to an induction of TRPA1 (Figure 1). Of note, the activation of NRF2 can also induce detoxifying enzymes [84,85] in this way inactivating potential carcinogens (Figure 1) leading to a complex picture, in which chemosensory TRP channels exert pivotal, regulatory functions.

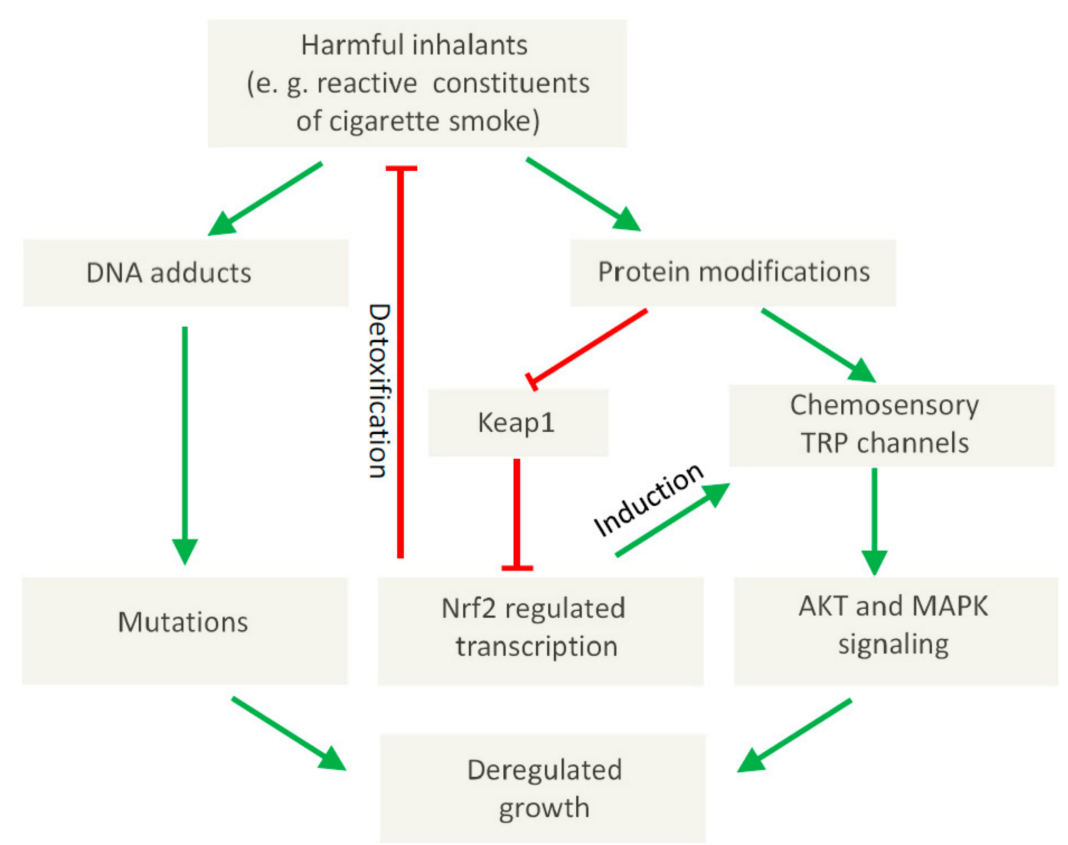

Figure 1. Proposed involvement of chemosensory TRP channels in tumor-promoting molecular effects elicited by harmful inhalants. 


\section{Outlook}

Chemosensory TRP channels such as TRPA1, TRPV1, and TRPV4 have emerged as important regulators of the epithelial integrity and mucociliary clearance of the airways. They are activated by exposure to potentially harmful inhalants (diesel exhaust, formalin, acrolein) or known lung carcinogens (electrophilic components of cigarette smoke). The activation of these channels is associated with inflammatory effects in the bronchial system and, more important in the context of lung tumorigenesis, some TRP members are involved in the regulation of oncogenic signaling pathways and may be involved in tumor-promoting effects.

Owing to the expression of TRP channels on the plasma membrane and the existence of more or less selective channel blockers or activators, these proteins are accessible to drug interventions. Even some approved drugs or novel drugs in clinical trials are available, which modulate some potentially tumor-relevant TRP channels, e.g., GRC 17536 (TRPA1) [86], XEN-D0501 (TRPV1) [80], SB705498 (TRPV1) [87]. Therefore, the elucidation of the cancer-relevant effects of TRP channels has a high translational impact and may define novel targets for therapeutic intervention.

Author Contributions: Conceptualization, A.A., T.R.H.B.; Resources, A.A., T.R.H.B.; Writing-Original Draft Preparation, T.R.H.B., E.B., I.B., D.S.; Writing-Review \& Editing, T.R.H.B.; E.B.; A.A.; Project Administration, A.A.

Funding: This research received no external funding.

Conflicts of Interest: The authors declare no conflict of interest.

\section{Abbreviations}

COPD: chronic obstructive pulmonary disease; NSCLC: non-small cell lung cancer; OS: overall survival; SCLC: small cell lung cancer; TRP: transient receptor potential channel.

\section{References}

1. Wahbah, M.; Boroumand, N.; Castro, C.; El-Zeky, F.; Eltorky, M. Changing trends in the distribution of the histologic types of lung cancer: A review of 4,439 cases. Ann. Diagn. Pathol. 2007, 11, 89-96. [CrossRef] [PubMed]

2. Shea, M.; Costa, D.B.; Rangachari, D. Management of advanced non-small cell lung cancers with known mutations or rearrangements: Latest evidence and treatment approaches. Ther. Adv. Respir. Dis. 2006, 10, 113-129. [CrossRef] [PubMed]

3. Herbst, R.S.; Morgensztern, D.; Boshoff, C. The biology and management of non-small cell lung cancer. Nature 2018, 553, 446-454. [PubMed]

4. Moya-Horno, I.; Viteri, S.; Karachaliou, N.; Rosell, R. Combination of immunotherapy with targeted therapies in advanced non-small cell lung cancer (NSCLC). Ther. Adv. Med. Oncol. 2018, 10. [CrossRef] [PubMed]

5. Parkin, D.M.; Bray, F.; Ferlay, J.; Pisani, P. Global cancer statistics, 2002. CA Cancer J. Clin. 2005, 55, 74-108. [CrossRef] [PubMed]

6. Parkin, D.M.; Ferlay, J.; Curado, M.P.; Bray, F.; Edwards, B.; Shin, H.R.; Forman, B. Fifty years of cancer incidence: CI5 I-IX. Int. J. Cancer 2010, 127, 2918-2927. [CrossRef] [PubMed]

7. Califano, R.; Abidin, A.Z.; Peck, R.; Faivre-Finn, C.; Lorigan, P. Management of small cell lung cancer: Recent developments for optimal care. Drugs 2012, 72, 471-490. [CrossRef] [PubMed]

8. Shapovalov, G.; Ritaine, A.; Skryma, R.; Prevarskaya, N. Role of TRP ion channels in cancer and tumorigenesis. Semin. Immunopathol. 2016, 38, 357-369. [CrossRef] [PubMed]

9. Cosens, D.J.; Manning, A. Abnormal electroretinogram from a Drosophila mutant. Nature 1969, 224, $285-287$. [CrossRef] [PubMed]

10. Montell, C.; Rubin, G.M. Molecular characterization of the Drosophila trp locus: A putative integral membrane protein required for phototransduction. Neuron 1989, 2, 1313-1323. [CrossRef]

11. Venkatachalam, K.; Montell, C. TRP channels. Annu. Rev. Biochem. 2007, 76, 387-417. [CrossRef] [PubMed]

12. Clapham, D.E. TRP channels as cellular sensors. Nature 2013, 426, 517-524. [CrossRef] [PubMed]

13. Ramsey, I.S.; Delling, M.; Clapham, D.E. An introduction to TRP channels. Annu. Rev. Physiol. 2006, 68, 619-647. [CrossRef] [PubMed] 
14. Bandell, M.; Macpherson, L.J.; Patapoutian, A. From chills to chilis: Mechanisms for thermosensation and chemesthesis via thermoTRPs. Curr. Opin. Neurobiol. 2007, 17, 490-497. [CrossRef] [PubMed]

15. Montell, C. The TRP superfamily of cation channels. Sci. STKE 2005, 272, 3. [CrossRef] [PubMed]

16. Rohacs, T. Regulation of transient receptor potential channels by the phospholipase $C$ pathway. Adv. Biol Regul. 2013, 53, 341-355. [CrossRef] [PubMed]

17. Hardie, R.C. TRP channels and lipids: From Drosophila to mammalian physiology. J. Physiol. 2007, 578, 9-24. [CrossRef] [PubMed]

18. Dietrich, A.; Kalwa, H.; Gudermann, T. TRPC channels in vascular cell function. Thromb. Haemost. 2010, 103, 262-270. [PubMed]

19. Caterina, M.J.; Rosen, T.A.; Tominaga, M.; Brake, A.J.; Julius, D. A capsaicin-receptor homologue with a high threshold for noxious heat. Nature 1999, 398, 436-441. [CrossRef] [PubMed]

20. Fleig, A.; Penner, R. The TRPM ion channel subfamily: Molecular, biophysical and functional features. Trends Pharmacol. Sci. 2004, 25, 633-639. [CrossRef] [PubMed]

21. Duncan, L.M.; Deeds, J.; Hunter, J.; Shao, J.; Holmgren, L.M.; Woolf, E.A.; Tepper, R.I.; Shyjan, A.W. Down-regulation of the novel gene melastatin correlates with potential for melanoma metastasis. Cancer Res. 1998, 1998 58, 1515-1520.

22. Nilius, B.; Prenen, J.; Owsianik, G. Irritating channels: The case of TRPA1. J. Physiol. 2011, 589, $1543-1549$. [CrossRef] [PubMed]

23. Hinman, A.; Chuang, H.H.; Bautista, D.M.; Julius, D. TRP channel activation by reversible covalent modification. Proc. Natl. Acad. Sci. USA 2006, 103, 19564-19568. [CrossRef] [PubMed]

24. Macpherson, L.J.; Dubin, A.E.; Evans, M.J.; Marr, F.; Schultz, P.G.; Cravatt, B.F.; Patapoutian, A. Noxious compounds activate TRPA1 ion channels through covalent modification of cysteines. Nature 2007, 445, 541-545. [CrossRef] [PubMed]

25. Bessac, B.F.; Jordt, S.E. Sensory detection and responses to toxic gases: Mechanisms, health effects, and countermeasures. Proc. Am. Thorac. Soc. 2010, 7, 269-277. [CrossRef] [PubMed]

26. Steinritz, D.; Stenger, B.; Dietrich, A.; Gudermann, T.; Popp, T. TRPs in Tox: Involvement of Transient Receptor Potential-Channels in Chemical-Induced Organ Toxicity-A Structured Review. Cells 2018, 7, 98. [CrossRef] [PubMed]

27. Büch, T.; Schäfer, E.; Steinritz, D.; Dietrich, A.; Gudermann, T. Chemosensory TRP channels in the respiratory tract: Role in toxic lung injury and potential as 'sweet spots' for targeted therapies. Rev. Physiol. Biochem. Pharmacol. 2013, 165, 31-65. [PubMed]

28. Taylor-Clark, T.E. Role of reactive oxygen species and TRP channels in the cough reflex. Cell Calcium. 2016, 60, 155-162. [CrossRef] [PubMed]

29. Geppetti, P.; Patacchini, R.; Nassini, R.; Materazzi, S. Cough: The Emerging Role of the TRPA1 Channel. Lung 2010, 188, 63-68. [CrossRef] [PubMed]

30. Bessac, B.F.; Jordt, S.E. Breathtaking TRP channels: TRPA1 and TRPV1 in airway chemosensation and reflex control. Physiology 2008, 23, 360-370. [CrossRef] [PubMed]

31. Kannler, M.; Lüling, R.; Yildirim, A.Ö.; Gudermann, T.; Steinritz, D.; Dietrich, A. TRPA1 channels: Expression in non-neuronal murine lung tissues and dispensability for hyperoxia-induced alveolar epithelial hyperplasia. Pflugers Arch. 2018, 470, 1231-1241. [CrossRef] [PubMed]

32. Büch, T.R.; Schäfer, E.A.; Demmel, M.T.; Boekhoff, I.; Thiermann, H.; Gudermann, T.; Steinritz, D.; Schmidt, A. Functional expression of the transient receptor potential channel TRPA1, a sensor for toxic lung inhalants, in pulmonary epithelial cells. Chem. Biol. Interact. 2013, 206, 462-471. [CrossRef] [PubMed]

33. Nassini, R.; Pedretti, P.; Moretto, N.; Fusi, C.; Carnini, C.; Facchinetti, F.; Viscomi, A.R.; Pisano, A.R.; Stokesberry, S.; Brunmark, C.; Svitacheva, N.; et al. Transient receptor potential ankyrin 1 channel localized to non-neuronal airway cells promotes non-neurogenic inflammation. PLoS ONE 2010, 7, E42454. [CrossRef] [PubMed]

34. Andrade, Y.N.; Fernandes, J.; Vázquez, E.; Fernández-Fernández, J.M.; Arniges, M.; Sánchez, T.M.; Villalón, M.; Valverde, M.A. TRPV4 channel is involved in the coupling of fluid viscosity changes to epithelial ciliary activity. J. Cell Biol. 2005, 168, 869-874. [CrossRef] [PubMed]

35. Gradilone, S.A.; Masyuk, A.I.; Splinter, P.L.; Banales, J.M.; Huang, B.Q.; Tietz, P.S.; Masyuk, T.V.; Larusso, N.F. Cholangiocyte cilia express TRPV4 and detect changes in luminal tonicity inducing bicarbonate secretion. Proc. Natl. Acad. Sci. USA 2007, 104, 19138-19143. [CrossRef] [PubMed] 
36. Lorenzo, I.M.; Liedtke, W.; Sanderson, M.J.; Valverde, M.A. TRPV4 channel participates in receptor-operated calcium entry and ciliary beat frequency regulation in mouse airway epithelial cells. Proc. Natl. Acad. Sci. USA 2008, 105, 12611-12616. [CrossRef] [PubMed]

37. Seminario-Vidal, L.; Okada, S.F.; Sesma, J.I.; Kreda, S.M.; van Heusden, C.A.; Zhu, Y.; Jones, L.C.; O'Neal, W.K.; Penuela, S.; Laird, D.W.; et al. Rho signaling regulates pannexin 1-mediated ATP release from airway epithelia. J. Biol. Chem. 2011, 286, 26277-26286. [CrossRef] [PubMed]

38. Fernandes, E.S.; Fernandes, M.A.; Keeble, J.E. The functions of TRPA1 and TRPV1: Moving away from sensory nerves. Br. J. Pharmacol. 2012, 166, 510-521. [CrossRef] [PubMed]

39. Gudermann, T.; Flockerzi, V. TRP channels as new pharmacological targets. Naunyn Schmiedebergs Arch. Pharmacol. 2005, 371, 241-244. [CrossRef] [PubMed]

40. Monteith, G.R.; McAndrew, D.; Faddy, H.M.; Roberts-Thomson, S.J. Calcium and cancer: Targeting Ca ${ }^{2+}$ transport. Nat. Rev. Cancer 2007, 7, 519-530. [CrossRef] [PubMed]

41. Prevarskaya, N.; Zhang, L.; Barritt, G. TRP channels in cancer. Biochim. Biophys. Acta 2007, 1772, 937-946. [CrossRef] [PubMed]

42. Gkika, D.; Prevarskaya, N. Molecular mechanisms of TRP regulation in tumor growth and metastasis. Biochim. Biophys. Acta 2009, 1793, 953-958. [CrossRef] [PubMed]

43. Hantute-Ghesquier, A.; Haustrate, A.; Prevarskaya, N.; Lehen'kyi, V. TRPM Family Channels in Cancer. Pharmaceuticals 2018, 11, 58. [CrossRef] [PubMed]

44. Carlson, J.A.; Ross, J.S.; Slominski, A.; Linette, G.; Mysliborski, J.; Hill, J. Molecular diagnostics in melanoma. J. Am. Acad. Dermatol. 2005, 52, 743-775. [CrossRef] [PubMed]

45. Bodding, M. TRP proteins and cancer. Cell. Signal. 2007, 19, 617-624. [CrossRef] [PubMed]

46. Tsavaler, L.; Shapero, M.H.; Morkowski, S.; Laus, R. Trp-p8, a Novel Prostate-specific Gene, Is Up-Regulated in Prostate Cancer and Other Malignancies and Shares High Homology with Transient Receptor Potential Calcium Channel Proteins. Cancer Res. 2001, 61, 3760-3769. [PubMed]

47. Noyer, L.; Grolez, GP.; Prevarskaya, N.; Gkika, D.; Lemonnier, L. TRPM8 and prostate: A cold case? Pflugers Arch. 2018, 470, 1419-1429. [CrossRef] [PubMed]

48. Fonseca, B.M.; Correia-da-Silva, G.; Teixeira, N.A. Cannabinoid-induced cell death in endometrial cancer cells: Involvement of TRPV1 receptors in apoptosis. J. Physiol. Biochem. 2018, 74, 261-272. [CrossRef] [PubMed]

49. Ligresti, A.; Moriello, A.S.; Starowicz, K.; Matias, I.; Pisanti, S.; De Petrocellis, L.; Laezza, C.; Portella, G.; Bifulco, M.; Di Marzo, V. Antitumor activity of plant cannabinoids with emphasis on the effect of cannabidiol on human breast carcinoma. J. Pharmacol. Exp. Ther. 2006, 318, 1375-1387. [CrossRef] [PubMed]

50. Contassot, E.; Tenan, M.; Schnüriger, V.; Pelte, M.F.; Dietrich, P.Y. Arachidonyl ethanolamide induces apoptosis of uterine cervix cancer cells via aberrantly expressed vanilloid receptor-1. Gynecol. Oncol. 2004, 93, 182-188. [CrossRef] [PubMed]

51. Wissenbach, U.; Niemeyer, B.A.; Fixemer, T.; Schneidewind, A.; Trost, C.; Cavalie, A.; Reus, K.; Meese, E.; Bonkhoff, H.; Flockerzi, V. Expression of CaT-like, a novel calcium-selective channel, correlates with the malignancy of prostate cancer. J. Biol. Chem. 2001, 276, 19461-19468. [CrossRef] [PubMed]

52. Jaquemar, D.; Schenker, T.; Trueb, B. An ankyrin-like protein with transmembrane domains is specifically lost after oncogenic transformation of human fibroblasts. J. Biol. Chem. 1999, 274, 7325-7333. [CrossRef] [PubMed]

53. Schenker, T.; Trueb, B. Down-regulated proteins of mesenchymal tumor cells. Exp. Cell Res. 1998, 239, 161-168. [CrossRef] [PubMed]

54. Story, G.M.; Peier, A.M.; Reeve, A.J.; Eid, S.R.; Mosbacher, J.; Hricik, T.R.; Earley, T.J.; Hergarden, A.C.; Andersson, D.A.; Hwang, S.W.; et al. ANKTM1, a TRP-like channel expressed in nociceptive neurons, is activated by cold temperatures. Cell 2003, 112, 819-829. [CrossRef]

55. Schaefer, E.A.M.; Stohr, S.; Meister, M.; Aigner, A.; Gudermann, T.; Buech, T.R.H. Stimulation of the chemosensory TRPA1 cation channel by volatile toxic substances promotes cell survival of small cell lung cancer cells. Biochem. Pharmacol. 2013, 85, 426-438. [CrossRef] [PubMed]

56. Jordt, S.E.; Bautista, D.M.; Chuang, H.H.; McKemy, D.D.; Zygmunt, P.M.; Hogestatt, E.D.; Meng, I.D.; Julius, D. Mustard oils and cannabinoids excite sensory nerve fibres through the TRP channel ANKTM1. Nature 2004, 427, 260-265. [CrossRef] [PubMed] 
57. Kobayashi, K.; Fukuoka, T.; Obata, K.; Yamanaka, H.; Dai, Y.; Tokunaga, A. Distinct expression of TRPM8, TRPA1, and TRPV1 mRNAs in rat primary afferent neurons with adelta/c-fibers and colocalization with trk receptors. J. Comp. Neurol. 2005, 493, 596-606. [CrossRef] [PubMed]

58. Luo, W.; Wickramasinghe, S.R.; Savitt, J.M.; Griffin, J.W.; Dawson, T.M.; Ginty, D.D. A hierarchical NGF signaling cascade controls Ret-dependent and Ret-independent events during development of nonpeptidergic DRG neurons. Neuron 2007, 54, 739-754. [CrossRef] [PubMed]

59. Obata, K.; Katsura, H.; Mizushima, T.; Yamanaka, H.; Kobayashi, K.; Dai, Y.; Fukuoka, T.; Tokunaga, A.; Tominaga, M.; Noguchi, K. TRPA1 induced in sensory neurons contributes to cold hyperalgesia after inflammation and nerve injury. J. Clin. Investig. 2005, 115, 2393-2401. [CrossRef] [PubMed]

60. Bellono, N.W.; Bayrer, J.R.; Leitch, D.B.; Castro, J.; Zhang, C.; O’Donnell, T.A.; Brierley, S.M.; Ingraham, H.A.; Julius, D. Enterochromaffin Cells Are Gut Chemosensors that Couple to Sensory Neural Pathways. Cell 2017, 170, 185-198. [CrossRef] [PubMed]

61. Doihara, H.; Nozawa, K.; Kojima, R.; Kawabata-Shoda, E.; Yokoyama, T.; Ito, H. QGP-1 cells release 5-HT via TRPA1 activation; a model of human enterochromaffin cells. Mol. Cell. Biochem. 2009, 331, 239-245. [CrossRef] [PubMed]

62. Nozawa, K.; Kawabata-Shoda, E.; Doihara, H.; Kojima, R.; Okada, H.; Mochizuki, S.; Sano, Y.; Inamura, K.; Matsushime, H.; Koizumi, T.; et al. TRPA1 regulates gastrointestinal motility through serotonin release from enterochromaffin cells. Proc. Natl. Acad. Sci. USA 2009, 106, 3408-3413. [CrossRef] [PubMed]

63. Purhonen, A.K.; Louhivuori, L.M.; Kiehne, K.; Kerman, K.E.; Herzig, K.H. TRPA1 channel activation induces cholecystokinin release via extracellular calcium. FEBS Lett. 2008, 582, 229-232. [CrossRef] [PubMed]

64. Du, G.J.; Li, J.H.; Liu, W.J.; Liu, Y.H.; Zhao, B.; Li, H.R.; Hou, X.D.; Li, H.; Qi, X.X.; Duan, Y.J. The combination of TRPM8 and TRPA1 expression causes an invasive phenotype in lung cancer. Tumour Biol. 2014, 35, 1251-1261. [CrossRef] [PubMed]

65. Ramer, R.; Hinz, B. Inhibition of cancer cell invasion by cannabinoids via increased expression of tissue inhibitor of matrix metalloproteinases-1. Natl. Cancer Inst. 2008, 100, 59-69. [CrossRef] [PubMed]

66. Thomas, K.C.; Sabnis, A.S.; Johansen, M.E.; Lanza, D.L.; Moos, P.J.; Yost, G.S.; Reilly, C.A. Transient receptor potential vanilloid 1 agonists cause endoplasmic reticulum stress and cell death in human lung cells. J. Pharmacol. Exp. Ther. 2007, 321, 830-838. [CrossRef] [PubMed]

67. Reilly, C.A.; Taylor, J.L.; Lanza, D.L.; Carr, B.A.; Crouch, D.J.; Yost, G.S. Capsaicinoids cause inflammation and epithelial cell death through activation of vanilloid receptors. Toxicol. Sci. 2003, 73, 170-181. [CrossRef] [PubMed]

68. Sadofsky, L.R.; Ramachandran, R.; Crow, C.; Cowen, M.; Compton, S.J.; Morice, A.H. Inflammatory stimuli up-regulate transient receptor potential vanilloid-1 expression in human bronchial fibroblasts. Exp. Lung Res. 2012, 38, 75-81. [CrossRef] [PubMed]

69. Li, X.; Zhang, Q.; Fan, K.; Li, B.; Li, H.; Qi, H.; Guo, J.; Cao, Y.; Sun, H. Overexpression of TRPV3 Correlates with Tumor Progression in Non-Small Cell Lung Cancer. Int. J. Mol. Sci. 2016, 17, 437. [CrossRef] [PubMed]

70. Brone, B.; Peeters, P.J.; Marrannes, R.; Mercken, M.; Nuydens, R.; Meert, T.; Gijsen, H.J. Tear gasses CN, CR, and CS are potent activators of the human TRPA1 receptor. Toxicol. Appl. Pharmacol. 2008, 231, 150-156. [CrossRef] [PubMed]

71. Taylor-Clark, T.E.; McAlexander, M.A.; Nassenstein, C.; Sheardown, S.A.; Wilson, S.; Thornton, J.; Carr, M.J.; Undem, B.J. Relative contributions of TRPA1 and TRPV1 channels in the activation of vagal bronchopulmonary C-fibres by the endogenous autacoid 4-oxononenal. J. Physiol. 2008, 586, 3447-3459. [CrossRef] [PubMed]

72. Trevisani, M.; Siemens, J.; Materazzi, S.; Bautista, D.M.; Nassini, R.; Campi, B.; Imamachi, N.; Andrè, E.; Patacchini, R.; Cottrell, G.S.; et al. 4-Hydroxynonenal, an endogenous aldehyde, causes pain and neurogenic inflammation through activation of the irritant receptor TRPA1. Proc. Natl. Acad. Sci. USA 2007, 104, 13519-13524. [CrossRef] [PubMed]

73. Andre, E.; Campi, B.; Materazzi, S.; Trevisani, M.; Amadesi, S.; Massi, .D; Creminon, C.; Vaksman, N.; Nassini, R.; Civelli, M.; et al. Cigarette smoke-induced neurogenic inflammation is mediated by alpha, beta-unsaturated aldehydes and the TRPA1 receptor in rodents. J. Clin. Investig. 2008, 118, 2574-2582. [PubMed] 
74. Kichko, T.I.; Kobal, G.; Reeh, P.W. Cigarette smoke has sensory effects through nicotinic and TRPA1 but not TRPV1 receptors on the isolated mouse trachea and larynx. Am. J. Physiol. Lung Cell Mol. Physiol. 2015, 309, L812-L820. [CrossRef] [PubMed]

75. Stenger, B.; Zehfuss, F.; Mückter, H.; Schmidt, A.; Balszuweit, F.; Schäfer, E.; Büch, T.; Gudermann, T.; Thiermann, H.; Steinritz, D. Activation of the chemosensing transient receptor potential channel A1 (TRPA1) by alkylating agents. Arch. Toxicol. 2015, 89, 1631-1643. [CrossRef] [PubMed]

76. Takahashi, N.; Mizuno, Y.; Kozai, D.; Yamamoto, S.; Kiyonaka, S.; Shibata, T.; Uchida, K.; Mori, Y. Molecular characterization of TRPA1 channel activation by cysteine-reactive inflammatory mediators. Channels 2008, 2, 287-298. [CrossRef] [PubMed]

77. McNamara, C.R.; Mandel-Brehm, J.; Bautista, D.M.; Siemens, J.; Deranian, K.L.; Zhao, M.; Hayward, N.J.; Chong, J.A.; Julius, D.; Moran, M.M.; et al. TRPA1 mediates formalin-induced pain. Proc. Natl. Acad. Sci. USA 2007, 104, 13525-13530. [CrossRef] [PubMed]

78. Schreiner, B.S.; Lehmann, R.; Thiel, U.; Ziemba, P.M.; Beltrán, L.R.; Sherkheli, M.A.; Jeanbourquin, P.; Hugi, A.; Werner, M.; Gisselmann, G.; et al. Direct action and modulating effect of (+)- and (-)-nicotine on ion channels expressed in trigeminal sensory neurons. Eur. J. Pharmacol. 2014, 728, 48-58. [CrossRef] [PubMed]

79. Talavera, K.; Gees, M.; Karashima, Y.; Meseguer, V.M.; Vanoirbeek, J.A.; Damann, N.; Everaerts, W.; Benoit, M.; Janssens, A.; Vennekens, R.; et al. Nicotine activates the chemosensory cation channel TRPA1. Nat. Neurosci. 2009, 12, 1293-1299. [CrossRef] [PubMed]

80. Nassini, R.; Gees, M.; Harrison, S.; De Siena, G.; Materazzi, S.; Moretto, N.; Failli, P.; Pretim, D.; Marchetti, N.; Cavazzini, A.; et al. Oxaliplatin elicits mechanical and cold allodynia in rodents via TRPA1 receptor stimulation. Pain 2011, 152, 1621-1631. [CrossRef] [PubMed]

81. Miyake, T.; Nakamura, S.; Meng, Z.; Hamano, S.; Inoue, K.; Numata, T.; Takahashi, N.; Nagayasu, K.; Shirakawa, H.; Mori, Y.; et al. Distinct Mechanism of Cysteine Oxidation-Dependent Activation and Cold Sensitization of Human Transient Receptor Potential Ankyrin 1 Channel by High and Low Oxaliplatin. Front. Physiol. 2007, 8, 878. [CrossRef] [PubMed]

82. Berrout, J.; Kyriakopoulou, E.; Moparthi, L.; Hogea, A.S.; Berrout, L.; Ivan, C.; Lorger, M.; Boyle, J.; Peers, C.; Muench, S.; et al. TRPA1-FGFR2 binding event is a regulatory oncogenic driver modulated by miRNA-142-3p. Nat. Commun. 2017, 8, 947. [CrossRef] [PubMed]

83. Takahashi, N.; Chen, H.Y.; Harris, I.S.; Stover, D.G.; Selfors, L.M.; Bronson, R.T.; Deraedt, T.; Cichowski, K.; Welm, A.L.; Mori, Y.; et al. Cancer Cells Co-opt the Neuronal Redox-Sensing Channel TRPA1 to Promote Oxidative-Stress Tolerance. Cancer Cell 2018, 33, 985-1003. [CrossRef] [PubMed]

84. Jaramillo, M.C.; Zhang, D.D. The emerging role of the Nrf2-Keap1 signaling pathway in cancer. Genes Dev. 2013, 27, 2179-2191. [CrossRef] [PubMed]

85. Taguchi, K.; Motohashi, H.; Yamamoto, M. Molecular mechanisms of the Keap1-Nrf2 pathway in stress response and cancer evolution. Genes Cells 2011, 16, 123-140. [CrossRef] [PubMed]

86. Skeratt, S. Recent Progress in the Discovery and Development of TRPA1 Modulators. Prog. Med. Chem. 2017, 56, 81-115.

87. Gibson, R.A.; Robertson, J.; Mistry, H.; McCallum, S.; Fernando, D.; Wyres, M.; Yosipovitch, G. A randomised trial evaluating the effects of the TRPV1 antagonist SB705498 on pruritus induced by histamine, and cowhage challenge in healthy volunteers. PLoS ONE 2014, 9, e100610. [CrossRef] [PubMed]

(C) 2018 by the authors. Licensee MDPI, Basel, Switzerland. This article is an open access article distributed under the terms and conditions of the Creative Commons Attribution (CC BY) license (http://creativecommons.org/licenses/by/4.0/). 